\title{
Analysis of Key Influencing Factors of Construction Waste Treatment Based on Statistical Model
}

\author{
Xu Yihong and $\mathrm{He} \mathrm{Ge}$ \\ Jiang Han University Wuhan, 430056, China
}

\begin{abstract}
Keywords: construction and demolition waste; Solid Waste; Circular Economy; Waste Disposal and Recycling; statistics; environmental pollution; principal component analysis
\end{abstract} Abstract: how to deal with construction and demolition waste is a worldwide problem, especially in developing countries and areas. By analyzing and finding out those key factors that affect the treatment of construction and demolition waste, the author provides theoretical support for local government, enterprises producing construction and demolition waste and disposal establishment holding the development direction and points of handling construction and demolition waste, and it is a piece of pleasurable work. PPS and Principal Component Analysis are used to investigate and survey 738 samples from 13 urban areas in Wuhan, and MATLAB software is employed to solve latent root related to matrix. Besides, the method of SPSS is adopted to make statistical analysis work well in its validity and reliability. It ranks those predominant factors of dealing with construction and demolition waste and draws 5 aspects of important points that affect disposing construction and demolition waste,including all field management show no motivation to disposing of construction and demolition waste.

\section{Introduction}

In China, it was defined in a book named Technical Code for Construction and Demolition Waste Treatment that all kinds of solid waste produced in the course of construction, convertion, decoration, demolishment and installation on different kinds of buildings, structures and its support facilities includes muck, waste concrete, rubble, waste asphalt, waste pipe and waste wood.

Currently, mainly solution of construction and demolition waste was to bury it underground directly and most of it, without any treatment, was used to backfill foundation pit and marsh land.Some waste was pile up in the construction site randomly. Even worse, some was poured into rivers and lakes directly, which cause water area decreasing day by day, waterlogging in rainy days getting worser and worser and serious secondary pollution to land and water source. At the same time, in the transport process, it contaminated the road constantly, which seriously affects the sanitation. Those waste, through environment protection treatment and recycling, only have 2 million tons, which means reject synthesis use factor achieves $0.4 \%$, almost negligible.

Therefore, in the face of severe construction waste siege situation, how to deal with and discharge of construction waste has become a different problem and real issue faced by many cities. This paper uses statistical methods to analyze the key factors influencing the construction waste, construction generated for local governments, enterprises that produce construction waste and enterprises that disposal of construction waste to grasp the development direction and focus, make full use of their own advantages and resources to play the potential to provide intellectual support and theoretical support.

\section{Literature review}

How to deal with the construction waste is an important problem faced by the whole world. In some developed countries, experts have already studied the theory and practice of construction waste in an early time and made a lot of achievement. They mainly do research in these aspects: (1) Analysing the source of construction waste, classification analysis and yield estimation research. (2)Research on the causes of construction waste (Gabilan, 1994; Vender, 1996);Step Smolensk and Bowen, 1996; Carbon, 
1998; Gadewer, 1998; Rich Wood, 2002; Toadflax, 2004); (3)Analysis that weather the construction waste can be recycled.(Sturm, 1989; Perera, 2006; Rolf, 2008) (4) Research on the mode of managrment of recycling utilization of construction waste ( Skowron, 1976; Smith, 1993; Horton, 1994; Busenke, 1996; Kinbecte, 1997; Kohler, 1997; James, 2004; Pirlo, 2004; Denison, 1990; Tom, 2008; Nicolas, 2009; Isabel Martinez, 2010),etc.

Taken together, foreign countries research deeper on construction waste and their research field is wider for they have corresponding research on both the producing of construction waste and the solution of it. Therefore, some opinions and experience of those foreign researchers can be used for reference, including:(1) It is not because of lacking of technology but lack of energy to translate the construction waste into useful resource that makes the dealing with waste difficult. Construction waste resources do not have the value of the currency of the market economy because from the perspective of traditional economic values, translating construction waste into resources are not enough to make up the cost of speeding. (2) Strategy of source reduction" is the most effective method to control the problem. It means that through effective management methods and strict legal means to control the production of construction waste. (3) Using recycling technology and the government's positive guidance can promote the construction waste to maximize the use of regeneration.

Related research at china on construction waste is a little late. Some specialists do researches on following aspects: current situation of construction waste solution, problems and countermeasures, translating the waste into resource, industrializing construction waste, especially in the research of recycling technology of wastet concrete and waste brick, they made a lot of achievements. There are some representative researchers, such as (Liweixin, 2000; Yanghaiyin, 2009; Zhengkaideng, 2004; Limeirong, 2006; Wongweisu and Liuzhongyang , 2008 \& Chenhanming, 2008). they have published many theoretical and practical articles.

In early 2000, Qinhuangdao Metallurgical Design and Research Institute and other six units do a joint research project, aims to break through the treatment of construction waste and recycling, which is a material about recycled aggregate comprehensive feasibility, the performance of recycled concrete, practical research, this is the earlier practice study on construction waste disposal problem.

The legislative work of construction waste in our country began in 1980s. In 1996, the Ministry of Construction promulgates the "city construction waste management regulations", to promote the construction waste recycling management, has played a significant role in creating a good living environment. But it is just a lack of normative documents, the actual strength. In 2000, the Ministry of Construction start working on amending "city construction waste management regulations". In 2001, it promulgated the "City Housing Demolition Management Regulations". In 2002, the Ministry of construction, the State Planning Commission jointly issued the "on promoting the city sewage and garbage disposal industrialization development view" In 2005, the implementation of "People's Republic of China solidwaste pollution prevention law" helps to develop more construction waste into the legal management of the track. In addition, the State Council and the Ministry of Construction issued a series of rules, regulations, constituting China's laws and regulations on construction waste management frame.

From a comprehensive study of domestic experts and scholars, we can see that most studies either from a purely technical point of view of technology of recycling waste concrete and brick, or from the analysis of the current situation of construction waste management, to find out the existing problems at present and then put forward the corresponding countermeasures and suggestions on the basis of relevant experience of developed countries. The following aspects should be strengthened:(1) the disposal of construction waste involved in construction engineering, environment science, chemistry, etc. It is an interdisciplinary subject. Their research on can not be compared with traditional disciplines. (2) Establish a statistical system of construction waste disposal and collect detailed statistical data. (3)Using quantitative model and combining the city areas to analyse help to support and promote the standards and regulatory policies. 


\section{Research and design}

Many factors will have an influence on the way we deal with construction and demolition wastes, whereas what are the key factors is the issue deserving our meditation and deep exploration. This article which takes Wuhan City, Hubei Province as an example will analyze the key factors on dealing with construction and demolition wastes with statistical analysis method.

Wuhan, as an important city rising in Centre China, has made increasingly progress in the building of social infrastructure, the promotion of urbanization, the construction of towns' infrastructure and the rebuilding of old urban area. According to an uncomprehensive statistics, by the end of the year 2015, the number of construction sites in Wuhan has amounted to 12981 including 12321 house construction sites and 660 municipal construction sites, which produce sixty million tons of wastes every year. It is assumed that during The thirteenth Five-Year Plan Wuhan shall produce about 66,110,000 tons of solid wastes, which means 13,220,000 tons per year. After selection, available solid wastes in practice are approaching 10,580,000 every year.

The respondents of this research includes 700 households from 35 streets in 7 administrative districts (Jiang'an District, Jianghan District, Wuchang District, Hongshan District, Caidian District, Jiangxia District and Xinzhou District), 60 employees from government departments and 39 representatives from environmental enterprises focusing on construction solid wastes. 799 questionnaires in total were delivered and 738 of them were effective, a total recovery rate of 92.36 .

The research combines stratified sampling and multi-stage cluster sampling methods as well as interviewing residents face to face.

\subsection{Stratified sampling}

Wuhan consists of 13 administrative districts which is divided into Centre City Area and New City Area. The Centre City Area includes Jiang'an District, Jianghan District, Wuchang District, Qiaokou District, Hanyang District, Hongshan District and Qingshan District; the New City Area includes Donghu District, Caidian District, Jiangxia District, Huangpi District, Xinzhou District and Hannan District.

\subsection{Three-stage sampling}

The first-stage PPS sample adopts various probability sample method. The second-stagePPS sampling is in the first phase sampling the primary sample unit of the second unit. The third-stage balanced system sampling adopts the method of simple random sampling without putting back for the residents with equal rate sample.

\subsection{The determination of sample size}

We assume that $\mathrm{n} 0$ is the best sample size, $\mathrm{t}$ is the critical value under some confidence coefficient, $\mathrm{p}$ is the sample proportion and $d$ is the absolute error. When the confidence coefficient is $95 \%, t=1.96$. The population of permanent residents in Wuhan is $\mathrm{N}=10,220,000$, the population in the Centre City Area is $=6,340,000$, and the population in the New City Area is =3,880,000.

$$
\begin{aligned}
& n_{0}=\frac{t^{2} P Q / d^{2}}{1+\frac{1}{N}\left(\frac{t^{2} P Q}{d^{2}}-1\right)} \\
& V(p)=\frac{p(1-p)}{n_{0}} \frac{N-n_{0}}{N-1}
\end{aligned}
$$

NPC Allocation Formula: 


$$
n_{k}=n \frac{w_{k} S_{h}}{\sum_{h=1}^{L} w_{h} S_{h}}=n \frac{N_{h} S_{h}}{\sum_{h=1}^{L} N_{h} S_{h}}(h=1,2, \ldots L)
$$

To calculate: $\quad$ Deff $\approx 2$

$$
\begin{aligned}
& \mathrm{n}=\mathrm{n} 0 \text { 。 Deff } \approx 738 \\
& n 1=n \frac{N 1 S 1}{\sum_{k=1}^{2} N k S k}=468 \\
& n 2=n \frac{N 2 S 2}{\sum_{k=1}^{2} N_{k} S k}=270
\end{aligned}
$$

\section{The data analysis}

\subsection{Information and validity test}

The questionnaire of this research, The Key Factors Which Has an Influence on How to Deal with the Construction and Demolition Wastes in Wuhan, includes 15 questions in total. 150 people from Hanyang District and Caidian District were inquired at random and finally 125 questionnaires were returned. After verification, 108 questionnaires are effective among those 125 ones.

\subsubsection{Project identification test}

The projects with good degree of differentiation can be distinguished by different level. The item discrimination index $(\mathrm{D}=\mathrm{Ph}-\mathrm{P} 1)$ can be used to measure the repartition table of project. Discrimination index refers to scale to quantify the answer of question score, and the more dispersed the score of the sample in the project is, the more distinctive the differences are. The sample is divided into two groups according to the scores, with $\mathrm{Ph}$ and $\mathrm{P} 1$, respectively high score group and the low score group of ratios (Table1) .

Table1: Evaluation form of project identification index

\begin{tabular}{|c|c|}
\hline \multicolumn{2}{|c|}{ Project identification test } \\
\hline Identification Index & $\begin{array}{c}\text { Judgement of the } \\
\text { questions }\end{array}$ \\
\hline over 0.40 & Very good \\
\hline $0.30-0.39$ & $\begin{array}{l}\text { Good, need some } \\
\text { odification }\end{array}$ \\
\hline $0.20-0.29$ & $\begin{array}{c}\text { Average, need } \\
\text { amendment }\end{array}$ \\
\hline Less than 0.20 & $\begin{array}{c}\text { Poor, must be } \\
\text { weeded ou }\end{array}$ \\
\hline
\end{tabular}

Three questions, Q8, Q9, Q10 is used as the identification project to testify those respondents and the lowest score of the group of high score is 3, and the highest score of the group of low score is 2(Table 2) . 
Table2: The percentage of each item takes in high and low score group

\begin{tabular}{|c|c|c|}
\hline Number & $\begin{array}{c}\text { The percentage in } \\
\text { low score group }\end{array}$ & $\begin{array}{c}\text { The } \\
\text { percentage } \\
\text { in high score } \\
\text { group }\end{array}$ \\
\hline Q8 & $10.36 \%$ & $89.64 \%$ \\
\hline Q9 & $31.1 \%$ & $68.9 \%$ \\
\hline Q10 & $24.65 \%$ & $75.35 \%$ \\
\hline
\end{tabular}

Then we worked out the item identification index by calculation so that a result that their identification indexes are above 0.40 was recovered, which shows that the design of those five questions is reasonable and the answers of the inquired unit have identification.

Above all, the questionnaires that are tested by the experimental research results pass through item identification check.

\subsubsection{Information inspection}

Use retest reliability method to test the reliability of questionnaires (Table 3) .

Table3:The Coefficient Scale

\begin{tabular}{|c|c|}
\hline Numerical Interval & Meaning \\
\hline over0.9 & $\begin{array}{c}\text { Scale reliability is very } \\
\text { good }\end{array}$ \\
\hline $0.8-09$ & Scale reliability is good \\
\hline $0.7-0.8$ & $\begin{array}{c}\text { Some items need to be } \\
\text { modified, available still }\end{array}$ \\
\hline $0.6-0.7$ & $\begin{array}{c}\text { Some items need to be } \\
\text { amended, available yet }\end{array}$ \\
\hline Less than 0.60 & $\begin{array}{c}\text { Some items need to be } \\
\text { weeded out }\end{array}$ \\
\hline
\end{tabular}

Three questions, Q8, Q9, Q10, are respectively tested with retest reliability method, and the following is the result, (Table 4).

Table4:The Reliability Inspection Table

\begin{tabular}{|c|c|c|}
\hline Item Significance & $\begin{array}{c}\text { Correlat } \\
\text { ion } \\
\text { coefficie } \\
\text { nt }\end{array}$ & Meaning \\
\hline $\begin{array}{c}\text { The recognition obtained } \\
\text { from construction wastes }\end{array}$ & 0.816 & Good \\
\hline $\begin{array}{c}\text { The situation of recycling } \\
\text { construction wastes }\end{array}$ & 0.785 & Good \\
\hline $\begin{array}{c}\text { The present situation of } \\
\text { construction wastes }\end{array}$ & 0.852 & Good \\
\hline
\end{tabular}

From the results, correlation coefficient is above 0.7 , which means the scale reliability is receivable. Above all, the scale consistency is high and the questionnaires have reliability.

\subsection{The analysis on key factors having an influence on construction and demolition wastes}

\subsubsection{A descriptive analysis}

First, The essential situation of the respondents. According to the online analytical processing report and frequency analysis, the effective questionnaires in total are 738. The males of those questionnaires 
are $198,26.83 \%$ of the total number; females are $540,73.17 \%$ of the people; the respondents under 16 years old are 50, 6.71\% of the total respondents, respondents from 16 to 25 are $607,82.32 \%$, the respondents from 25 to 35 are 58, $7.39 \%$, respondents above 35 are $23,3.05 \%$.

Second, The respondents' understanding of construction wastes. The statistics shows that the number of respondents who understand construction wastes a lot take a proportion of $4.58 \%$, the number of respondents who know about it take a proportion of $7.08 \%$, those who know a little about it take a proportion of $56.67 \%$ and those who know nothing about it take a proportion of $31.67 \%$.Among these respondents, the number of people who think construction waste is extremely dangerous to human take a proportion of $34.76 \%$, those who think it is dangerous take a proportion of $54.88 \%$, those who think it does no harm to human take a proportion of $4.27 \%$ and those who do not know take a proportion of $6.1 \%$.

According to the analysis, we can see that respondents who don't know much about construction waste take a proportion of $36.25 \%$ while those who think construction waste do harm to people take a proportion of $89.63 \%$.

Third, Subjects were aware of the recycling of construction waste. The statistics shows that the number of respondents who have awareness in recycling construction wastes take a proportion of $16.46 \%$, the number of respondents who occasionally have awareness in recycling construction wastes is $52.44 \%$, while those respondents who do not have awareness to recycling construction wastes take a proportion of $31.1 \%$. In addition, the respondents who know the ways to deal with construction wastes is $12.2 \%$, those who just know a little is $29.27 \%$, and those who don't know is $58.54 \%$.

So, we can work out that the respondents who have awareness to recycle construction wastes in daily life takes a proportion of $68.9 \%$ and the respondents who learn about the ways to deal with those wastes is $21.47 \%$.

\subsubsection{Principal component analysis determines the key factors which have influence on dealing with} the construction and demolition wastes.

$$
\begin{gathered}
S=(s i j)_{p} * p=\frac{1}{n-1} \sum_{k-1}^{n}(x k i-\overline{x i})(x k j-\overline{x j})^{T} \\
R=(r i j)_{p} * p=\left[\frac{s i j}{\sqrt{S i i * s j j}}\right] \\
s i j=\frac{1}{n-1} \sum_{k=1}^{n}(x k i-\overline{x i})(x k j-\overline{x j})
\end{gathered}
$$

When we design the index which has an influence on dealing with construction wastes, according to these analysis above, we determine five indexes. They are respectively the understanding about how to deal with construction wastes(X1), the awareness to recycle construction wastes(X2), the enterprises' recognition of construction wastes(X3), the government's opinion on those wastes(X4) and other factors(X5).

Based on the primary index system, we use expert scoring method and principal factor analysis method to decide the main factor indexes. But because of the limited resource we have to use the public scoring method in which we will work out the mean and the variance to replace the expert scoring method. So they score the above five factors and we according to the importance of those factors work out the score of each factor ranging from 0 to 9 . The higher the score is, the more important the influence is; the lower the score is, the less important the influence is.

To abstract 50 questionnaires at random from the total samples, and then put back, and then abstract 50 questionnaires again ...just do like that for 7 times. Among this the mean of each group is eliminated and then we can see the score results of the seven groups. Table 5 shows it. 
Table5: The table of experts' scoring

\begin{tabular}{|c|c|c|c|c|c|}
\hline Group Number & $\boldsymbol{X 1}$ & $\boldsymbol{X} \mathbf{X}$ & $\boldsymbol{X 3}$ & $\boldsymbol{X 4}$ & $\boldsymbol{X 5}$ \\
\hline 1 & 5.44 & 5.92 & 5.46 & 5.78 & 4.36 \\
\hline 2 & 5.84 & 6.24 & 5.94 & 5.68 & 4.38 \\
\hline 3 & 5.84 & 6.19 & 5.77 & 5.69 & 4.79 \\
\hline 4 & 5.78 & 6.47 & 5.86 & 5.85 & 4.92 \\
\hline 5 & 5.22 & 6.25 & 5.54 & 5.64 & 5.85 \\
\hline 6 & 5.66 & 6.33 & 5.86 & 5.72 & 5.96 \\
\hline 7 & 5.40 & 6.20 & 5.55 & 5.74 & 5.72 \\
\hline
\end{tabular}

The sample covariance matrix $\mathrm{S}$ :

$\left[\begin{array}{ccccc}0.06 & 0.015 & 0.04 & -0.002 & -0.08 \\ 0.015 & 0.028 & 0.22 & 0.002 & -0.08 \\ 0.04 & 0.22 & 0.036 & 0.001 & -0.021 \\ -0.002 & 0.002 & 0.001 & 0.005 & -0.013 \\ -0.08 & -0.08 & -0.021 & -0.013 & 0.478\end{array}\right]$

On account of the big difference of the diagonal factors in S, our sample relative matrix Rshows the principal factor analysis. It is:

$$
\left[\begin{array}{ccccc}
1 & 0.366 & 0.861 & -0.115 & -0.472 \\
0.366 & 1 & 0.693 & 0.169 & -0.692 \\
0.861 & 0.693 & 1 & 0.075 & -0.16 \\
-0.115 & 0.169 & 0.075 & 1 & -0.266 \\
-0.472 & -0.692 & -0.16 & -0.266 & 1
\end{array}\right]
$$

To use simulation software MATLAB to solve the above characteristics of the matrix related to the root, we can draw a cumulative contribution rate is greater than $90 \%$ of all the factors. It is as the Table 6.

Table6: Characteristic value table

\begin{tabular}{|c|c|c|c|}
\hline Characteristic value & $\boldsymbol{X 5}$ & $\boldsymbol{X 4}$ & $\boldsymbol{X 3}$ \\
\hline Characteristic root & 2.658 & 1.23 & 0.748 \\
\hline Contribution rate (\%) & 53.16 & 24.6 & 14.96 \\
\hline $\begin{array}{c}\text { Cumulative contribution } \\
\text { rate (\%) }\end{array}$ & 53.16 & 77.76 & 92.72 \\
\hline
\end{tabular}

From the result, we can know that the cumulative contribution rate of enterprises' influences on dealing with construction wastes, government's influences on dealing with construction wastes and other factors' influences on dealing with construction wastes is above $90 \%$, so that we can assume that the three factors are the key ones which have an important influence on construction wastes, and we can use these three factors to replace the original five ones.

Use Likert 5 choices to deeply analysis the present situation and reason of dealing with construction wastes. To apply mathematics statistical formula:

$$
\begin{gathered}
A V i=\frac{\sum_{j=1}^{N} X_{i j}}{N} \\
S D i=\sqrt{\frac{\sum_{j=1}^{N}(X i j-A V i)^{2}}{N}}
\end{gathered}
$$


$\mathrm{AV}_{\mathrm{ij}}$ is the average score of $\mathrm{I}, X_{i j}$ is the score of $\mathrm{i}$ in levelI- $\mathrm{V}$, and $\mathrm{N}$ is the total number of the questionnaires. Use a software SPSS to analysis and work out the average score $A V_{i}$ and the standard deviation $\mathrm{SD}_{\mathrm{i}}$, and then to make them in order comparatively.

According to the data from Q9, we analysis the factors of dealing with construction wastes as Table 7.

Table7: The survey of the opinions on present situation and reason of dealing with construction wastes

\begin{tabular}{|c|c|c|c|c|c|}
\hline Factors & $\begin{array}{c}\text { Couldn't agree any } \\
\text { more(\%) }\end{array}$ & Agree (\%) & $\begin{array}{c}\text { Averag } \\
\boldsymbol{e}(\%)\end{array}$ & $\begin{array}{c}\text { Don't } \\
\text { agree(\%) }\end{array}$ & Don't agree very much(\%) \\
\hline Q10.1 & 3.2 & 8.6 & 3.2 & 33.4 & 51.6 \\
\hline Q10.2 & 6.5 & 50.5 & 16.1 & 23.7 & 3.2 \\
\hline Q10.3 & 2.2 & 42.8 & 16.5 & 352 & 33 \\
\hline Q10.4 & 4.3 & 35.5 & 10.8 & 36.5 & 12.9 \\
\hline Q10.5 & 28.0 & 54.8 & 8.6 & 6.5 & 2.1 \\
\hline Q10.6 & 9.8 & 40.2 & 20.7 & 23.9 & 5.4 \\
\hline Q10.7 & 6.5 & 50.0 & 16.3 & 21.8 & 2.4 \\
\hline Q10.8 & 22.0 & 54.9 & 6.6 & 14.3 & 0 \\
\hline Q10.9 & 20.4 & 62.4 & 7.5 & 9.7 & 2.1 \\
\hline Q10.10 & 58.1 & 36.6 & 2.1 & 1.1 & 3.2 \\
\hline Q10.11 & 15.0 & 61.3 & 14.0 & 6.5 & 0 \\
\hline Q10.13 & 30.1 & 60.2 & 5.4 & 4.3 & 9.7 \\
\hline Q10.14 & 5.4 & 40.9 & 19.3 & 24.7 & 4.3 \\
\hline
\end{tabular}

The survey lists fourteen influential factors (from Y1 to Y14). From the perspective of architecture engineers, we should evaluate what influences these factors will have and find out the key factors to provide evidence for further analysis. Therefore, we can use Likert 5 choices to analysis the pesent situation and reason of construction wastes. Table 8 shows it.

Among the top five factors in those fourteen ones, Y10 has the highest score which is 4.437. Respondents widely think that the government's policy, technology and lacking funds should account for the low rate of recycling construction wastes. Others in order is Y12, Y5, Y9 and Y8, whose score is respectively 4.161, 4.0, 3.935 and 3.802. So lack of construction wastes management plan in the construction sites, lack of understanding and energy to deal with wastes and no classification of the wastes are the main three reasons for low rate of wastes cycling. On the other hand, we know that among those factors Y1 has the lowest score which is only 1.785 , which means the respondents have realized that construction and demolition wastes have a negative influence but now the ways of construction cannot decrease effectively the produce of wastes.

\section{Conclusion}

Through empirical analysis, the key factors influencing the construction waste treatment includes: (1) The government must have adquant policy, technology and financial support in dealing with the construction and demolition waste. (2)Those who neglect classifying the construction waste and dump it indiscriminately should be punished harder. (3) It lacks of construction waste management plan in the construction site. (4)The managers at the site always show little enthusiasm to disposal of the construction waste. (5)At the construction site, management is not so good that cause material waste. 


\section{References}

[1] Cochran K. M., Townsend T. G. Estimating construction and demolition debris generation using a materials flow analysis approach[J]. Waste Management, 2010, 30(11): 2247-2254.

[2] D. Kornack and P. Rakic, "Cell Proliferation without Neurogenesis in Adult Primate Neocortex," Science, vol. 294, Dec. 2001, pp. 2127-2130, doi:10.1126/science.1065467.

[3] Lengfaguang and Hegengxin,etc.Present situation and development trend of domestic and foreign construction waste resource.Environmental health engineering.2009,2,VOL.17,(1):33-35.

[4] Liuwei,Natural Resource Economics of chian. 2009 ,(5):24-26.

[5] Liuxiaofang.The problems and Countermeasures of Wuhan city construction waste disposal.The wall materials innovation and building energy saving2013(11):P48-50.

[6] Vivian W.Y. Tam, C.M. Tam,A review on the viable technology for construction waste recycling [J].Resources, Conservation and Recycling,2006(47):209-221.

[7] W. Zhao, R.B. Leeftink, V.S. Rotter,Evaluation of the economic feasibility for the recycling of construction and demolition waste in China-The case of Chongqing [J], Resources, Conservation and Recycling,2010(54):377-389.

[8] Yuanfang,Liqiming.A empirical study on the resource value of construction solid waste. [EB/OL]. (2011-06-13)[2012-09-28].http://www.cn-hw.net/html/sort069/201106/27913.html

[9] Yost P. A., Halstead J. M. A methodology for quantifying the volume of construction waste[J].Waste Management \& Research, 1996, 14(5): 453-461.

[10]Zhoujiawen.Investigation and countermeasure analysis of construction waste in the Pearl River Delta region., 2011.in a journal

[11]Zuoya. Research of Chinese construction waste resource utilization and recommendations[D], 2015. 